\title{
Research on the Influence of Urban Road Construction on the Quality of Life of Residents
}

\author{
Lu-Cang WANG ${ }^{a}$, Fei CHEN ${ }^{\text {b.* }}$ \\ Northwest Normal University, Lanzhou, China \\ aWanglc007@nwnu.edu.cn, ${ }^{\mathrm{b}} 17794255978 @ 163 . c o m$ \\ College of Geography and Environmental Science, \\ * Fei CHEN
}

Key words: Urban road construction, Quality of life of residents, Cheng County.

\begin{abstract}
The construction of urban roads could increased movement of goods and facility for people's trip, and promotes regional economic development. However, the construction of urban roads has two sides on city development. This paper after fact finding at Xiaochuan Rd in Cheng County by the form of the literature search and the questionnaire. Through investigate the influence of residents' quality of life during the road construction and the evaluation of construction achievements after the completion of the construction to reflect the advantages and disadvantages of the existing problems of road construction, residents' opinion on the new roads. To reflect the people's real life state and demand.
\end{abstract}

\section{Introduction}

In recent years, the scale of the city is increasing, and the urban planning plays an important role in the development of all aspects of the city. In this paper, by Xiaochuan road and surrounding residents as the research object, through a questionnaire survey on the new city road surrounding residents, understand the change of settlements around the natural and human environment before and after the road construction. In order to evaluate the cities in the process of urbanization, the influence of road construction on surrounding residents that found into the advantages and disadvantages of the existing county road construction.

\section{The Study Area Profile}

Cheng County belongs to Longnan City, located in the south of the Gansu Province, Jiang Wu Road from east to west through it. With the construction of Shitian highway, Tianwu railway and Longnan civil airport, the county will become the transportation hub of the Longnan City, the important center of trade and logistics. The Xiaochuan Road begins at Beiguan Road, terminating in Longnan Avenue, the total length of the road is $2.83 \mathrm{~km}$ (It is show in Fig.1 ).As a newly building road in recent years, the Xiaochuan Road has its special place.

According to the purpose of the road, it can be divided into three segments: The first paragraph, from Beiguan Road to the North Tonggu Road. This section belongs to the life road, it is mainly provide services for the residents that living in the neighborhood. The second paragraph, from Tonggu north road to the East of Dexian bridge .It belongs to the traffic road. Because of it connect with the Tonggu Road and the Xibin North Road, and the Dexian bridge is part of it, so it has High-volume traffic function. The third section, from the East of the Dexian Bridge to the Zhiqi road. This part belongs to the complex road of Commerce and transportation, which has the characteristics of large flow, high vehicle passing rate, fast speed etc. 


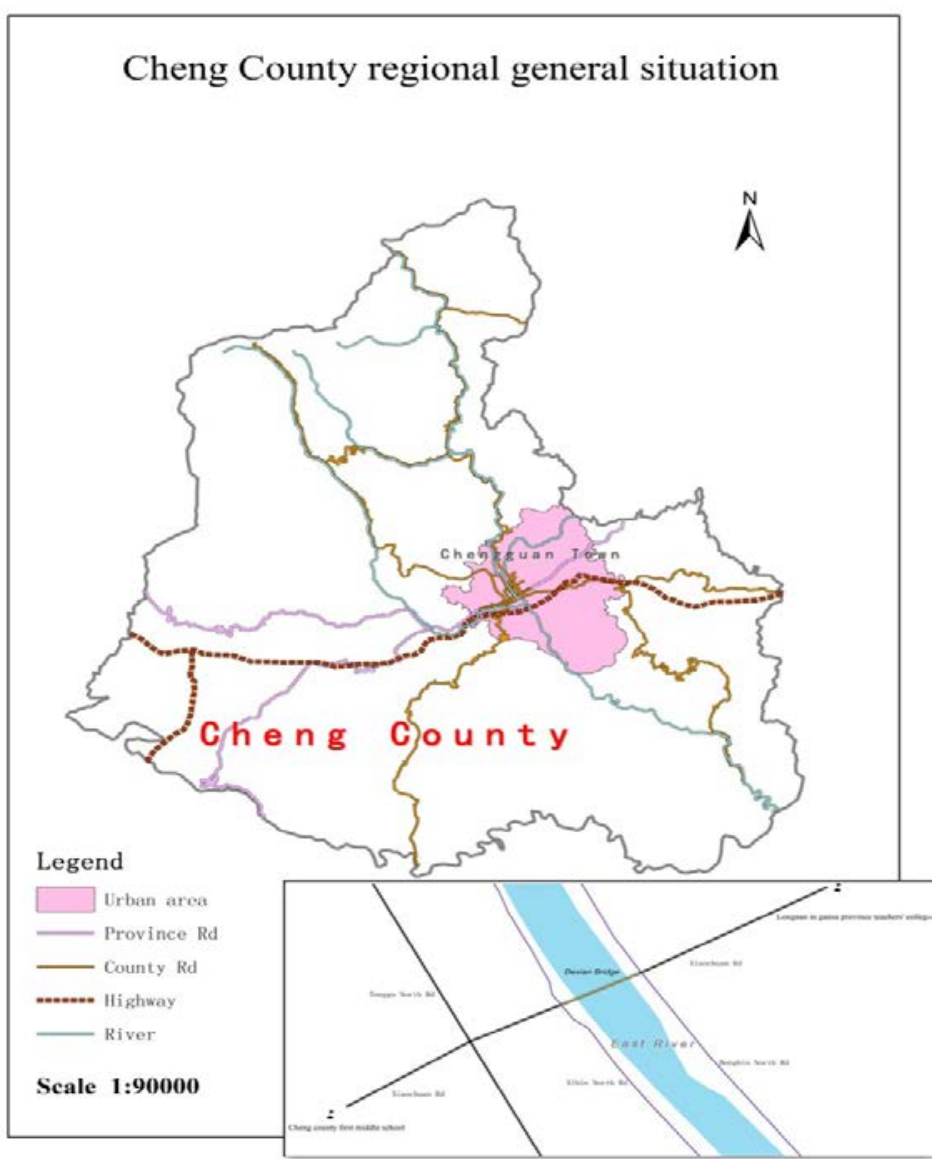

Fig.1 Cheng County regional general situation

\section{Investigation and Analysis}

\section{Questionnaire Design and Investigation}

The questionnaire is divided into two parts. The first part sets up 4 categories of the survey, it has 17 questions(It is show in eg: Table 1),Contents include:(1) the social attributes of the respondents;(2)the road trip change perception;(3) the impact of road construction;(4) recommendations for the construction of municipal roads. In the second part, according to the problems in the first part of the questionnaire, we design 15 questions (It is show in eg: Table 2),In order to make a comprehensive analysis of the overall quality of life to the residents.

\section{Social Attributes of the Object}

eg: Table 1 Contents of questionnaire

\begin{tabular}{|c|c|c|}
\hline Survey category & Number & Survey content \\
\hline Social attributes of respondents & 5 & Age, gender, education, occupation, residence \\
\hline Road trip change perception & 3 & Choice of transportation, safety hidden trouble, \\
convenient degree
\end{tabular}

The survey involved 282 people. As it shown in table 2, The subjects included different age, occupation, education level, and all kinds of people living in this area. The sample of the 
questionnaire has a wide coverage, and the social background of the respondents can basically meet the requirements. Therefore, the results of the questionnaire reflect the study result. It ensure the reliability of the results and the empirical analysis is based on the rationality of urban road planning.

eg: Table 2 basic information of respondents

\begin{tabular}{|c|c|c|c|c|c|c|c|}
\hline \multicolumn{2}{|c|}{ Social attribute } & \multirow{2}{*}{$\begin{array}{c}\text { Number } \\
173 \\
\end{array}$} & \multirow{2}{*}{$\begin{array}{c}\begin{array}{c}\text { Proportion } \\
(\%)\end{array} \\
61.35 \\
\end{array}$} & \multicolumn{2}{|r|}{ Social attribute } & \multirow{2}{*}{$\begin{array}{c}\text { Number } \\
147 \\
\end{array}$} & \multirow{2}{*}{$\begin{array}{c}\begin{array}{c}\text { Proportion } \\
(\%)\end{array} \\
52.13 \\
\end{array}$} \\
\hline \multirow{3}{*}{$\frac{8}{10}$} & Xiaochuan Rd & & & \multirow{2}{*}{$\frac{\mathfrak{9}}{9}$} & male & & \\
\hline & $\begin{array}{c}\text { Tonggu North } \\
\text { Rd }\end{array}$ & 109 & 38.65 & & female & 135 & 47.87 \\
\hline & Total: & 282 & 100 & \multirow{4}{*}{ 蛋 } & $<25$ & 68 & 24.11 \\
\hline \multirow{8}{*}{ 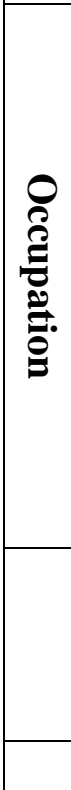 } & Farmer & 78 & 27.66 & & $25-45$ & 163 & 57.80 \\
\hline & Worker & 18 & 6.39 & & $>45$ & 51 & 18.09 \\
\hline & Student & 68 & 24.11 & & total: & 282 & 100 \\
\hline & Official & 22 & 7.80 & \multirow{5}{*}{ 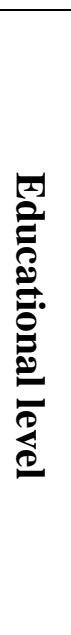 } & $\begin{array}{c}\text { Low education } \\
\text { (primary or below) }\end{array}$ & 38 & 13.48 \\
\hline & $\begin{array}{c}\text { Education, } \\
\text { science, health }\end{array}$ & 39 & 13.83 & & $\begin{array}{l}\text { Elementary } \\
\text { education }\end{array}$ & 42 & 14.89 \\
\hline & $\begin{array}{c}\text { Other } \\
\text { (self-employed, } \\
\text { migrant } \\
\text { workers, etc.) }\end{array}$ & 57 & 20.21 & & $\begin{array}{c}\text { Secondary } \\
\text { education (high } \\
\text { school, technical } \\
\text { secondary school) }\end{array}$ & 111 & 39.36 \\
\hline & & & & & $\begin{array}{l}\text { Higher education } \\
\text { (college degree, } \\
\text { bachelor degree or } \\
\text { above) }\end{array}$ & 91 & 32.27 \\
\hline & Total: & 282 & 100 & & Total: & 282 & 100 \\
\hline
\end{tabular}

\section{Survey of Residents' Living Conditions}

\section{Road Environment Satisfaction}

During the investigation in Xiaochuan Road, there are 173 questionnaires, all of them are effective. $40 \%$ of the residents believe that the road planning is reasonable, the road infrastructure is perfect.35\% of the residents feel that the new road is convenient for people to travel, and shorten the time of transportation. $30 \%$ of residents believe that the new road to ease the traffic problems, and reduce the probability of accidents. $26 \%$ of residents believe that the new road to make the residents who are living on both sides of the road to build the facade of the external rental investment. This not only promoted economic development, but also to facilitate the daily lives of residents. After the construction ,16\% of residents believe that the surrounding areas of domestic waste and other issues are unified planning and management by the municipal departments.

\section{Impact of New Roads on Residents}

In the survey of 282 villagers, 52.5\% people think that the new road will have a great impact on their living environment: The convenience of travel has been improved.40.4\% of people think that family income will increase. The newly built road has increased the business place of individual business households, a considerable number of residents increased rent income.13\% of people said that during the demolition of the surrounding residents of the normal travel caused inconvenience.

\section{Analysis of the Overall Quality of Life}

In the questionnaire data on the Xiaochuan road after finishing the first data weighted average 
method and deviation analysis of the study area residents overall quality of life satisfaction method. then, using the deviation analysis method for dimensional treatment of life satisfaction, finally draw the conclusion.

\section{Life Satisfaction}

The five options are "very satisfied", "satisfactory", "general", "not satisfied", "very dissatisfied" respectively represent the value of 5 points, 4 points, 3 points, 2 points, 1 points are calculated. The survey using the following formula index of satisfaction with the quality of life.

$$
\text { Formula for: } Z_{\mathrm{j}}=5 \times P_{j 5}+4 \times P_{j 4}+3 \times P_{j 3}+2 \times P_{j 2}+1 \times P_{j 1}(\mathrm{j}=1,2, \ldots, 15)
$$

Among them, $Z_{j}$ said the first $j$ project satisfaction average $(j=1,2, \ldots, 15)$ refers to the mean survey a total of 15 research projects, $P_{j 5}, P_{j 4}, P_{j 3}, P_{j 2}, P_{j 1}$ said "very satisfactory" on the project $\mathrm{j}$ respectively, "satisfactory", "general", "not satisfied", "extremely the number of full" percentage of respondents, finally get the results shown in Table 4.

\section{Life Satisfaction Survey Data Analysis}

eg: Table 4 residents' satisfaction with the overall quality of life of newly built roads

\begin{tabular}{|l|c|c|c|c|}
\hline & \multicolumn{2}{|c|}{ Xiaochuan Rd } & \multicolumn{2}{c|}{ Tonggu North Rd } \\
\hline & $\mathrm{Z}_{\mathrm{j}}$ & $D_{\mathrm{j}}$ & $\mathrm{Z}_{\mathrm{j}}$ & $D_{\mathrm{j}}$ \\
1.Economic income & 3.42 & 0.22 & 2.95 & -0.15 \\
2.Public order situations & 3.16 & -0.04 & 2.77 & -0.33 \\
3.Working condition & 2.90 & -0.30 & 2.92 & -0.18 \\
4.Consumption level & 2.69 & -0.51 & 2.63 & -0.47 \\
5.Living status & 3.31 & 0.11 & 3.30 & 0.20 \\
6.Living conditions & 3.33 & 0.13 & 3.23 & 0.13 \\
7.Reasonable planning & 3.41 & 0.21 & 3.26 & 0.16 \\
8.Health & 3.76 & 0.56 & 3.80 & 0.70 \\
9.Traffic safety & 3.67 & 0.47 & 3.57 & 0.47 \\
10.Environmental & 2.81 & -0.39 & 3.03 & -0.07 \\
condition & 2.15 & -1.05 & 2.44 & -0.66 \\
11.Impact during & 3.98 & 0.78 & 4.01 & 0.91 \\
construction & 3.53 & 0.33 & 2.68 & 0.42 \\
12.Traffic convenience & 2.65 & -0.55 & 2.77 & -0.33 \\
13.Demolition & 3.31 & 0.11 & 3.13 & 0.03 \\
resettlement & & & & \\
14.Infrastructure & & & & \\
construction & & & & \\
15.Overall quality of life & & & & \\
\hline
\end{tabular}

Xiaochuan road satisfaction index scores range from 2.15 to 3.98.Residents are most satisfied with the convenience of transportation, the most unsatisfactory is the adverse impact of the construction period to the residents' physical and mental health. The satisfaction index score of the same Tonggu North Road is between 2.44 and 4.01, The villagers are most satisfied with the convenience of transportation, the most dissatisfied with the construction impact. The consumption levels, environmental conditions, public security situation, working conditions, construction effects, and infrastructure construction of two research areas are negative. The social interaction, traffic conditions, living conditions, living conditions, living conditions, living conditions, demolition and resettlement, traffic convenience degree of these survey items are positive, indicating that residents are more satisfied with these projects. 


\section{Conclusion}

Based on the above analysis, the following conclusions are drawn: Cheng County road construction can greatly improve the city traffic conditions, and improve the living standards of residents. The impact of the natural environment, human environment, traffic safety, convenience of life, convenience of travel on the investigation that the residents in the region is significantly different from the residential area, residential environment, and the social attributes of the residents. After the construction of the road, that the original home base in the road construction area, is located on both sides of the road 5 meters to 10 meters of households affected by the larger, especially the impact on the street residents greater.

The residents are most concerned about the problem of resettlement, road safety problems and problems in the construction process, residents generally agreed that resettlement is reasonable, road safety is greatly improved, but still need to be further improved. During the adverse impact on the residents of the building is too large, embodied in the noise environment pollution.

\section{Acknowledgment}

This research is funded by the Natural Science Foundation of China (41261042).

\section{Reference}

[1] Chao YANG , Yanyan WEI. Urban traffic sustainable development index considering the quality of life [J] Journal of Tongji University, 2013, 41 (10)(In Chinese)

[2] Bao WEI. Humanized space of urban roads, Doctoral Dissertation of South China University of Technology, 2013.(In Chinese)

[3] Chunxiao XU, Jiang diffuse. City residents travel by high iron behavior intention formation mechanism of [J] human geography, 2014 (01) -0122-07.(In Chinese)

[4]Wangui CHENG, MingLU, ZhijuanYANG, et al. Effects of urban road construction on urban development [J] building materials development orientation, 2012 (4) (In Chinese)

[5] Xiaochuan road design calculations in 2010.Cheng county website.

[6] Cheng County local area controlled detailed planning. County Construction Bureau building Bulletin.

[7]Daiquan XIAO. The Study of Rescue System Construction Based on GIS-T for Urban Road Traffic Accident[A]. Intelligent Information Technology Application Association. Proceedings of the 2011 2nd Asia-Pacific Conference on Wearable Computing Systems (APWCS 2011) and 2011 International Conference on Intelligent Control and Information Technology (ICICIT 2011 V4)[C].Intelligent Information Technology Application Association:,2011:5.

[8]Miao Miao WANG, Jian Jun WANG, Hong Yan LIANG. Study on Traffic Impact Assessment of Urban Road Construction Projects[J]. Applied Mechanics and Materials, 2013, 2547(361):

[9] Daiquan XIAO. The Study of Rescue System Construction Based on GIS-T for Urban Road Traffic Accident[A]. Intelligent Information Technology Application Association. Proceedings of the 2011 2nd Asia-Pacific Conference on Wearable Computing Systems (APWCS 2011) and 2011 International Conference on Intelligent Control and Information Technology (ICICIT 2011 V4)[C].Intelligent Information Technology Application Association:,2011:5. 